OPEN ACCESS

International Journal of Management \& Entrepreneurship Research

P-ISSN: 2664-3588, E-ISSN:2664-3596

Volume 2, Issue 5, P.No. 344-352, October, 2020

Fair East Publishers

Journal Homepage: www.fepbl.com/index.php/ijmer

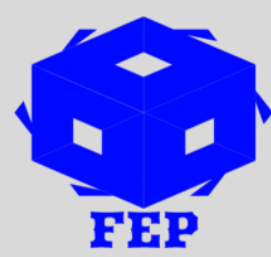

\title{
EQUITY AND CUSTOMER SATISFACTION IN RELATION TO PRODUCT QUALITY: AN EVIDENCE FROM THREE PRIVATE COMPANIES IN BURKINA FASO
}

\author{
Dr. Théophile Bindeouè Nassè ${ }^{2,3,4,5}$, Prof. Alidou Ouédraogo ${ }^{1}$, Dr. Stéphane Aimé Metchebon \\ Takougang ${ }^{2}$, Eric Zidouemba ${ }^{5}$ \\ ${ }^{1}$ University of Moncton, Moncton (Canada) \\ ${ }^{2}$ Aube Nouvelle University, Ouagadougou (Burkina Faso) \\ ${ }^{3}$ Saint Thomas d'Aquin University, Ouagadougou (Burkina Faso) \\ ${ }^{4}$ Thomas Sankara University, Ouagadougou (Burkina Faso) \\ Polytechnic College of Youth ${ }^{5}$
}

*Corresponding Author: Dr. Théophile Bindeouè Nassè

Corresponding Author Email: nassetheophile2009@gmail.com

Article Received: 15-09-20 Accepted: 05-10-20

Published: $15-10-20$

Licensing Details: Author retains the right of this article. The article is distributed under the terms of the Creative Commons Attribution-Non Commercial 4.0 License (http://www.creativecommons.org/licences/by-nc/4.0/) which permits non-commercial use, reproduction and distribution of the work without further permission provided the original work is attributed as specified on the Journal open access page.

\begin{abstract}
Previous studies in the context of Burkina Faso have shown the link between equity and customer relationship management. The purpose of the present study is to show the relationship between equity and customer satisfaction in relation to product quality. Equity and ethical practices in marketing are essential to competition and to the sustainable development of companies particularly in the West African Context. This research focuses on the contributions of fair business practices from business to customers in term of customer satisfaction in relation to product quality. Data collection is performed with a questionnaire addressed to customers of two Small and Medium Enterprises (SMEs) and one Very Small Enterprise (VSEs) in Burkina Faso. The quantitative data is processed using two different software SPSS and Sphinx IQ. The results show that in the three private companies there is a strong relationship between equity and customer satisfaction in relation to quality.

The recommendation is that equity and fair practices should be observed for a better management system of companies and for a maximum satisfaction of customers.
\end{abstract}

Keywords: Equity, Customer satisfaction, Quality, Marketing. 


\section{INTRODUCTION}

Burkina Faso's Small and Medium Enterprises (SMEs) and Very Small Enterprises (VSEs) face challenges in the national context and the international context where customers are committed to values such as integrity, justice, and fairness in trade. Some observations in the development of the different products and/ services show that their quality does not always meet the quality norms in the national context as well as in the international context. Thus, there is a need to observe some fair practices that will help to increase products quality as well as service quality. Many studies have shown that in an exchange situation, individuals compare the ratio with the offer as a repository and they can feel a sense of equity or non-equity (Adams, 1963; Peretti, 2004; Nassè, 2019). Some studies show that unfair situations always lead to injustice (Adams, 1963; Nassè, 2015). For other authors, the lack of equity can lead to customer dissatisfaction and disloyalty (Morrison, 2005; Nassè, 2019). However, in the context, some few studies have examined the relationship between equity and customer satisfaction, and there is no a deep knowledge about equity and customer satisfaction in relation to product quality. This present research aim is to put a light on this topic, and it is designed on the following question: What is the nature of the relationship between equity and customer satisfaction in relation to product quality?

The main objective here is to examine the relationship between equity and customer satisfaction.

The following section starts with a literature review that defines the concepts and shows the underpinning theory.

\section{LITERATURE REVIEW}

\section{The Research Concepts}

The Concept of Equity: The notion of equity is viewed as a distributive justice by some previous researchers such as Homans (1961) and Adams (1963). The concept of equity could be viewed as the perception that the client has of his investment in relation to a company's offer (Morrisson 2005). For further, the concept of equity is defined by Nasse (2019) as the perception of the offer by a given customer as compared to his/her investment.

The Concept of Satisfaction: This is the degree of joy, or the degree of happiness expressed by the customer about the products, the services and the capabilities of a given company (Vanhamme, 2004; Ladhari, 2005; Nassè, 2019). For some authors such as Tarigan, Darmasaputra, Ezra, Hatane, Lesmanaputri, and Firman (2020), satisfaction is a feedback that is a response to the customer's needs and expectations; and it is often expressed through pleasant emotions.

The Concept of Quality: Demeure (2008) views quality as the ability of a product to meet the core needs expressed by potential users or customers. For Demeure, the achievement of quality requires the control of quality in design, the control of quality in implementation, the control of quality in distribution, the deep implication of some key actors such as suppliers, customers, all the company's stakeholders, and the eradication of all sources of non-quality. The concept of quality is also viewed as an excellent service given to a given customer by some authors such as Abbasi, Umer, Sohail, Tang, Ullah, and Abbasi (2019).

\section{Underpinning Theories}

The Theory of Equity in Business Exchange: The theory of equity is based on fairness, distributive justice and it results from the comparison between what a customer perceives in an 
exchange "output, profit" and the contribution that the same customer makes to the exchange "input, investment" (Homans, 1961; Adams, 1963; Sabadie, 2000; Peretti, 2004; Morrison, 2005; Olsen, 2007; Nassè, 2019). For some authors, fair practices are essential for customer satisfaction (Morrison, 2005; Nassè, 2012; Nassè \& Sawadogo, 2019). For some authors the overall equity and internal equity particularly in the business-customer exchanges have an important place (Morrison, 2005, Nassè, 2019; Nassè \& Sawadogo, 2019).

The Theory of Satisfaction: The theory of satisfaction underlines that the satisfaction of a given customer on a particular product or particular service is driven by some particular needs and expectations (Vanhamme, 2004; Ladhari, 2005; Gandhi, 2011; Bashar, Ahmad \& Wasi, 2012; Nassè, 2019). Customer satisfaction is therefore linked to fair practices, equity, and it is characterized by emotional reactions. For some authors fairness is an antecedent to satisfaction (Vanhamme, 2004; Nassè, 2019).

The Theory of Quality: The theory of quality shows to what extend customer satisfaction is intrinsically associated to products quality or service quality (For Kotler \& Dubois, 2003; Demeure, 2008; Van Laethem \& Body, 2008; Nassè, 2019). The theory of quality also depicts how customers take into account, some fundamental criteria such as products' quality, and the associated services' quality (Nassè, 2019). However, product quality is often associated with its price. In the same way service quality is sometimes associated with its price.

These theories are approved because they are in line with the research topic and because they reveal the motivations and the expectations of customers towards fair and good practices, to make good predictions for a better management.

Thus, the conceptual framework here suggest that the perception of equity gives satisfaction to the customer, satisfaction is also a sign that there is equity. But, the non-perception of equity is a source of dissatisfaction. The previous studies suggested as solutions, reparations, compensations, reimbursements, the consideration of customer's needs and expectations whereas the present research suggests as solutions the consideration of customer's needs and expectations, hyper-personalization, reactivity, satisfactions surveys and customer recovery .

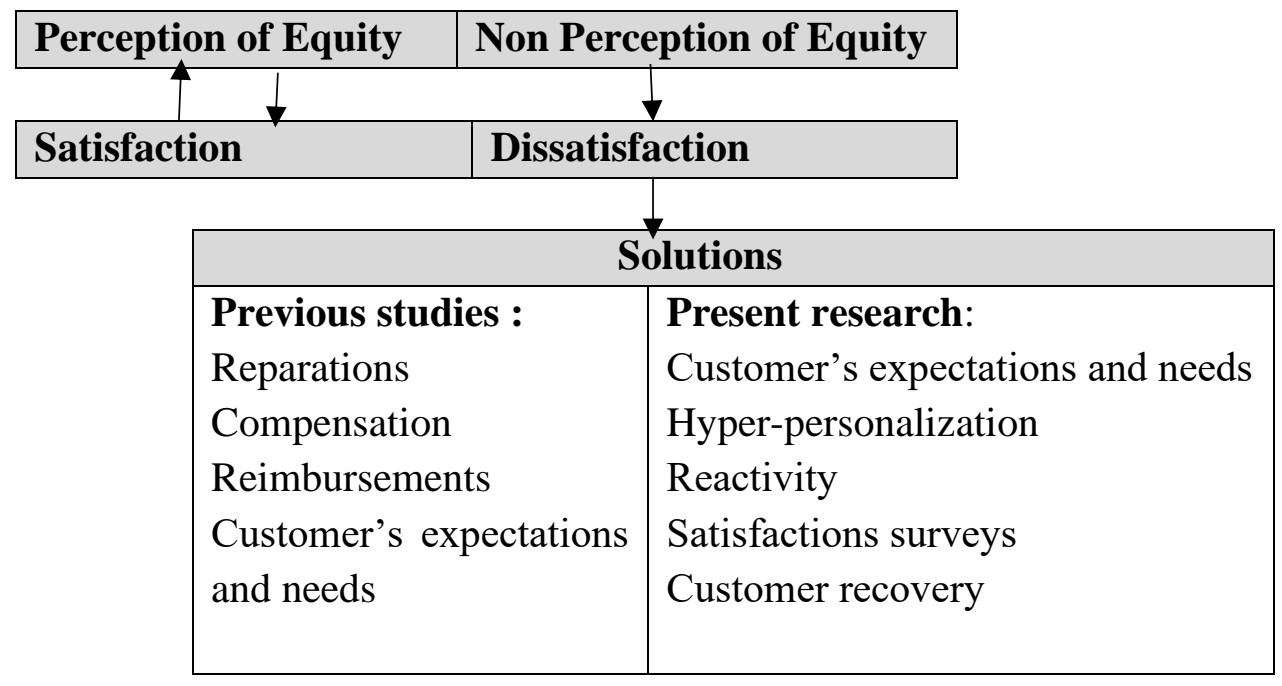

Figure 1- Conceptual Framework (Source : Fieldwork) 


\section{Research Model And Hypothesis}

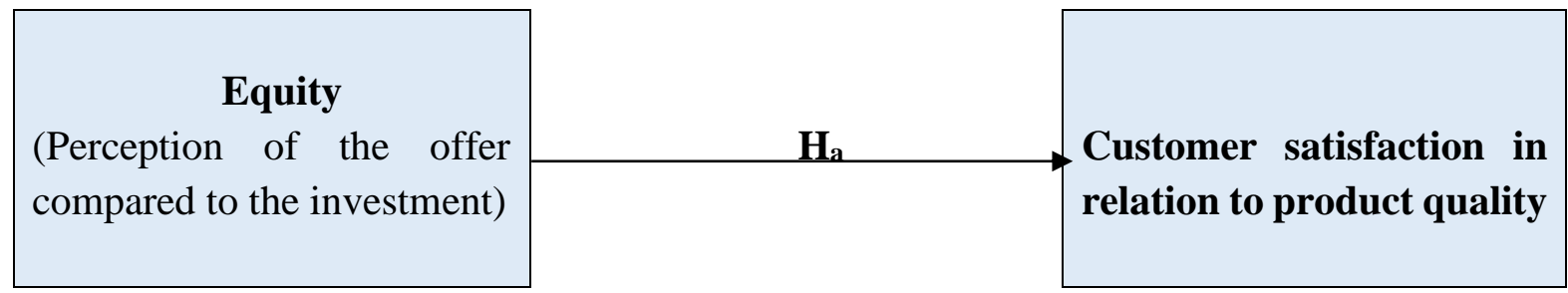

Figure 2 - Research Model (Source : Fieldwork)

The research here is trying to verify the following hypothesis :

- $\mathbf{H}_{\mathbf{a}}$ : Equity and customer satisfaction in relation to product quality are strongly associated.

- $\mathbf{H}_{\mathbf{0}}$ : Equity and customer satisfaction in relation to product quality are not strongly associated.

\section{RESEARCH METHODOLOGY}

- Epistemological Stance: The research is focused on a postpositivist stance with an approach that is mainly hypothetico-deductive (Nasse, 2019).

- Research Procedure: This research is conducted in two small and medium size companies and one very small company. The sampling procedure is a random sampling where all the respondent is selected independently from the same population (Anderson, Sweeney, Williams, Camm, \& Cochran, 2015). This sample is a subset of the studied population. The sample size is calculated using the formula by Ganassali (2009): $\mathrm{n}=(\mathrm{p} \times(1-\mathrm{p})) /(\mathbf{e} / 1.96)^{2}$; with $\mathrm{p}=$ the observed percentage; and $\mathrm{e}=$ maximum error. The number of respondent to question for an error of $0.65 \%$ is $n=0.25 /(0.065 / 1.96)^{2}=229$ respondents. The total number of respondents of the research is 233 .

- Research Instrument: This is a pretested questionnaire with 14 questions. This questionnaire is built using a Likert scale in four (4) items ranging from "Strongly disagree" to "Strongly agree". The questionnaire is pretested on 120 respondents and after the pretested the questions are reajusted to make them easily understandable.

- Research Setting: The research is conducted in the context of West Africa, precisely in Burkina Faso. The research field is limited to the main capital city, Ouagadougou for a period of one year. In this context, conducting a research in companies is very challenging, particularly in the government own companies, because the data is kept confidential, and its access to researchers is very restricted (Nasse, 2019). Therefore, the research is carried out in some private companies, particularly three (3) companies that have been very flexible to the request of conducting a research on equity and customer satisfaction in relation to their product quality or service quality.

- Research Participants: Participants include women and men who have an education level from primary level to university level. The participants are also considered in terms of age, gender, marital status, profession and social class. For instance, the age of participants is ranged from 10 to 60 years and above.

- Data Analysis: The collected data is processed with the Sphinx IQ quantitative version and the SPSS software version. 
- Validation of the Research: The research instruments are designed to better appreciate the phenomenon under examination and to view if it is efficiently measured (Carricano, Poujol, \& Bertrandias, 2010). The results are also post validated and the different respondents reiterate the same points of views.

- Viability of the Research: The results are tested several times to see if the results are the same. According to Carrino, Poujol, and Bertrandias (2010), the method of "test" and "retest" are the best manners to show research viability. The present results are tested several times and the conclusions are the same.

-Ethical considerations: Respondents' point of views is handle with attentiveness and a full consideration of their personality (Nassè, 2018; Nassè, 2020). Another consideration is that the researcher has given full respect to respondents to choose their own time and places to fill the questionnaire.

\section{RESEARCH RESULTS}

The total number of respondents is 233 respondents with a $100 \%$ response rate, with some into three sub samples $\left(\mathrm{N}_{\mathrm{a}}=\right.$ training center $=138$ respondents; $\mathrm{N}_{\mathrm{b}}=\mathrm{SARL}$ ENT $=49$ respondents; $\mathrm{N}_{\mathrm{c}}=$ restaurant $=46$ respondents $)$.

In company $\mathrm{A}$, the results of Table 1 reveal that the variable "equity" and the variable " customer satisfaction in relation to product or service quality" are strongly associated with a p-value $=$ $<0.01$ and $\chi^{2}=41.83$ and a degree of freedom $\mathrm{df}=9.00$. As a result, the null hypothesis $\left(\mathrm{H}_{0}\right)$ is rejected and the alternative hypothesis $\left(\mathrm{H}_{\mathrm{a}}\right)$ is verified.

\section{Company A (Training Center)}

Table 1

Correlations between Equity and Customer Satisfaction in relation to Quality

Variables Crossing Results

"Equity" and "customer satisfaction" $\quad \mathrm{p}=<0.01 ; \chi^{2}=41.83 ; \mathrm{df}=9.00$

The relationship is very significant.

*p $=<0.05 \quad$ Source: Fieldwork, 2014-2015

In company $\mathrm{B}$, the results of Table 2, reveal that the variable "equity" and the variable " customer satisfaction in relation to product or service quality" are strongly associated with a pvalue $=0.01$ and $\chi^{2}=16.63$ and a degree of freedom $\mathrm{df}=6.00$. Thus, the null hypothesis $\left(\mathrm{H}_{0}\right)$ is rejected and the alternative hypothesis $\left(\mathrm{H}_{\mathrm{a}}\right)$ is verified.

\section{Company B (Restaurant)}

Table 2

Correlations between Equity and Customer Satisfaction in relation to Quality

\begin{tabular}{cc}
\hline Variables crossing & \multicolumn{1}{c}{ Results } \\
\hline "Equity" and "customer satisfaction" & $\begin{array}{l}\mathrm{p}=0.01 ; \chi^{2}=16.63 ; \mathrm{df}=6.00 \\
\text { The relationship is very significant. }\end{array}$ \\
\hline$* \mathrm{p}=<0.05$ & \\
\hline & Source: Fieldwork, 2014-2015
\end{tabular}

In company $\mathrm{C}$, the results of Table 3 , reveal that the variable "equity" and the variable " customer satisfaction in relation to product or service quality" are strongly associated with a p- 
value $=0.01$ and $\chi^{2}=16.25$ and a degree of freedom $\mathrm{df}=6.00$. Consequently, the null hypothesis $\left(\mathrm{H}_{0}\right)$ is rejected and the alternative hypothesis $\left(\mathrm{H}_{\mathrm{a}}\right)$ is verified.

\section{Company C (Computer science and printing company)}

Table 3

Correlations between Equity and Customer Satisfaction in relation to Quality

\begin{tabular}{cl}
\hline \multicolumn{1}{c}{ Variables Crossing } & \multicolumn{1}{c}{ Results } \\
\hline "Equity" and "customer satisfaction" & $\mathrm{p}=0.01 ; \chi^{2}=16.25 ; \mathrm{df}=6.00$ \\
& The relationship is very significant.
\end{tabular}

\begin{tabular}{cc}
\hline $\mathrm{*} p=<0.05 \quad$ Source: Fieldwork, 2014-2015
\end{tabular}

\section{DISCUSSION OF THE RESULTS}

The different results show that the relationship between the variable "equity" and "customer satisfaction" are strong and very significant. Some previous researchers have pointed out that the success of any business should focus on fair practices and exchanges (Perreti, 2004; Hondeghem and Perry, 2009; Nasse, 2012; Akouwerabou and Bako, 2014; Nassè, 2019; Carbonell, Nassè, Ouédraogo, Kafimbou, Ampofo, \& Kinda, 2020). The present research has gone further to show through the results of the three (3) companies that, the perceived equity is a factor of customer satisfaction in relation to product quality or service quality. This means that equity is one important aspect for customer satisfaction in the context of Burkina Faso. The customer perceives equity when $\mathrm{s} / \mathrm{he}$ is satisfied about the product or the service quality. However, dissatisfaction in relation to product or service quality demonstrates that there is a weakness to meet equity requirements, and the different customer's expectations and needs in term of fair practices.

\section{CONCLUSION}

The present research contributes to the development of the concept of equity and the concept of satisfaction through a review of recent literature. Another contribution is that the present research provides some managerial contributions for managers to improve the quality of products and the quality of services in order to meet customers' need and expectation. It is clear that fair practices contribute to the economic development of companies; an economic development that is necessary for the eradication of poverty, to the creation of jobs and wealth and the basis of sustainable development.

- Recommendations for Firms: There is a need to put an emphasis on the hyper-reactivity and the hyper-personalization of the needs and expectations of the customers in the context.

There is a necessity to put an emphasis on fair practices in term of products' quality and/or service quality that are significant for customer satisfaction. Improving the quality of products and services is good for the companies' competitivity and for them to face the challenges of the international market.

-Recommendations for Governmental Authorities: It is vital to always control the quality of products on the different markets and to make sure that they are good for consumption. Thus, it is also good to encourage companies to manufacture some excellent products and to provide services by sensitizing them to avoid poor quality products, counterfeit products or poor quality services. 
-Future Research: The researchers are looking to investigate the relationship between equity and customer satisfaction in relation to product price or service price.

\section{Acknowledgements}

The research team wants to acknowledge the efforts made by the various respondents, and the support of the editorial board of the International Journal of Management \& Entrepreneurship Research. We are also deeply indebted to Dr. Théophile Bindeouè Nassè for his contributions.

\section{Conflict of Interest Statement}

No conflict of interest has been declared by the authors.

\section{References}

Abbasi, B. N., Umer, M., Sohail, A., Tang, J., Ullah, I., \& Abbasi, H. (2019). Service quality, customer satisfaction and loyalty in banking sector of Pakistan. International Journal of Management \& Entrepreneurship Research, 1(1), 1-8.

Adams, J. S. (1963). Towards an understanding of inequity. Journal of Abnormal and Social Psychology, 1(67), 422-436.

Anderson, D. R., Sweeney, D. J., Williams, T. A., Camm, J. D., \& Cochran, J. J. (2015). Statistiques pour l'économie et la gestion (5ème éd.). Paris, PA: Distribution Nouveaux Horizons.

Bashar, A., Ahmad, I. \& Wasi, M. (2012). A study of influence of demographic factors on consumer impulse buying behaviour. International Journal of Management and Strategy, 3(5), 1-18.

Borg, C., \& Blidner-Knittel, C. (2009). Sales channels connection to marketing communication and customer relationships. Gothenburg, GO: University of Gothenburg.

Bourgoin, H. (1984). L'Afrique malade du management. Paris, PA: J. Picollec.

Bressy, G., \& Konkuyt, C. (2004). Économie d'entreprise, 6 ème éd. Paris, PA : Dalloz.

Brewer, G. A., \& Selden, S. C. (2000). Why elephants gallop: assessing and predicting organizational performance in federal agencies. Journal of Public Administration Research and Theory, 10(4), 685 - 711.

Carbonell, N., Nassè, T. B., Ouédraogo, A., Kafimbou, B. H., Ampofo, A. J. \& Kinda, M. (2020). Recruitment methods and performance: an evidence from businesses in Burkina Faso. International Journal of Management \& Entrepreneurship Research, 2 (4), 265274.

Carrino, M., Poujol F., \& Bertrandias, L. (2010). Analyse des données avec SPSS (2 ème éd.). Paris, PA : Pearson éducation.

Demeure, C. (2008). Marketing, (6 ème éd.). Paris, PA : Dunod.

Ganassali, S. (2009). Les enquêtes par questionnaires avec sphinx. Paris, PA: Pearson Éducation.

Gandhi, S. (2011). Customer satisfaction, its antecedent and linkage between employee satisfaction and customer satisfaction: a study. Asian Journal of Business and Management Sciences, 1(1), 129-137.

Homans, G. C. (1961). Social behavior: its elementary forms. London, LO: Routlege and Kegan Paul. 
Hondeghem, A., \& Perry, J. L. (2009). Numéro spécial du GEAP sur la motivation de service public et la performance. Revue Internationale Des Sciences Administratives, 75(1), 510.

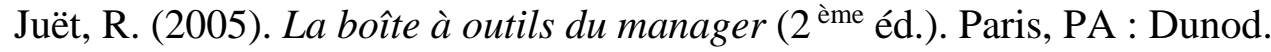

Kotler, P., \& Dubois, B. (2003). Marketing management (11 ème éd.). Pearson, Paris, France.

Ladhari, R. (2005). La satisfaction du consommateur : ses déterminants et ses conséquences. Revue de l'Université de Moncton, 36(2), 171-201.

Morrisson, O. (2005). Influence modératrice de l'équité externe sur la relation disconfirmation des attentes - satisfaction à l'égard des actions de service recovery. Université Lyon 3.

Morrisson, O., \& Mathieu, J. P. (2003). Représentations du dysfonctionnement d'un service et les réponses de l'entreprise. 8èmes journées de recherche en marketing de Bourgogne, Dijon, France.

Nassè, T. B. (2020). Investigating religious beliefs, consumption and interreligious dissimilarities and similarities in Low Income Countries: a mixed research with reference to Traditionalist, Christian and Muslim consumers in Burkina Faso. International Journal of Social Sciences Perspectives, 7(2), 71-80. https://doi.org/https://doi.org/10.33094/7.2017.2020.72.71.80.

Nassè, T. B. (2019). Internal equity and customer relationship management in developing countries: A quantitative and a comparative study of three private companies in Burkina Faso. African Journal of Business Management, 13(1), 37-47.

Nassè, T. B., \& Sawadogo, M. Y. (2019). Internal equity and customer relationship management in subsistence markets: a comparative and a qualitative study of three private companies in Burkina Faso. International Journal of Management \& Entrepreneurship Research, 1(1), 42-58.

Nassè, B. T. (2018). Pratiques religieuses et comportement de consommation dans un contexte africain : une étude exploratoire sur les consommateurs au Burkina Faso. Thèse de doctorat en sciences de gestion, spécialité marketing. Ouagadougou, OU: Université Aube Nouvelle et Université Cheikh Anta Diop.

Nassè, B. T. (2016). La place de l'équité interne dans la gestion de la relation client. Journal Ouest Africain de Sciences de Gestion, 1(1), 38-54.

Nassè, T. B. (2015). Internal equity as a factor of companies' economic profitability: A comparative study of three private companies in Burkina Faso through a qualitative approach. Saarbrucken, SA: Lamber Academic Publishing.

Nassè, B. T. (2012). The place of internal equity in customer relationship management: an evidence from the Language Learning and Translation Center. Saarbrucken, SA: Lamber Academic Publishing.

Olsen, L. L. (2002). Modeling equity, satisfaction and loyalty in business to consumer markets. Norway, NO : Norwegian school of management.

Ouédraogo, A. (2007). Strategic management in African firms: a local perspective. Problems and Perspectives in Management, 5(1), 82-94.

Ouédraogo, A. (2006). Innovation, compétitivité et croissance des PME : expériences de deux Entreprises du secteur biotechnologique au Québec. Les actes du $5^{e}$ congrès de l'académie de l'entreprenariat. Sherbrooke, SH: Université de Sherbrooke.

Perconte, B. (2003). 50 fiches pour comprendre le marketing (2 ème éd). Paris, PA : Bréal. 
Perreti, J. M. (2004). Les clés de l'équité : enjeu managérial. Paris, PA : Éditions d'Organisation.

Sabadie, W. (2000). Les apports des théories de la justice au marketing des services. Montréal, MO: AFM.

Tarigan, J., Darmasaputra, A., Ezra, V., Hatane, S. E., Lesmanaputri, E., \& Firman, J. J. P (2020). Linking customer satisfaction to shareholders value: evidence from Indonesia listed company. SHS Web of Conferences, 76(01017), 1-12.

Van Laethem, N., \& Body, L. (2008). Le plan marketing (2 ème éd). Paris, PA : Dunod.

Vanhamme, J. (2004). La surprise et son influence sur la satisfaction des consommateurs: synthèse des recherches et implications managériales. Revue Française du Marketing, 197(1), 46-47. 